\title{
Analisis Numerik Tekuk Kolom Variasi Penampang Profil Baja Tunggal
}

\author{
BIQI BANUSHA, ERMA DESIMALIANA \\ Program Studi Teknik Sipil, Institut Teknologi Nasional Bandung, Indonesia \\ Email: ermadesmaliana@itenas.ac.id
}

\begin{abstract}
ABSTRAK
Permasalahan yang umumnya sering terjadi pada kolom bangunan yaitu deformasi tekuk. Deformasi tekuk dapat terjadi jika suatu kolom dibebani oleh gaya aksial tekan yang nilainya besar. Penelitian ini bertujuan untuk menganalisis kekuatan desain kolom dan membandingkan nilai beban tekuk dan faktor panjang tekuk, baik dengan menggunakan perhitungan AISC maupun pemodelan software ANSYS. Kolom dengan variasi penampang profil baja IWF, $C, T, L$, Hollow Square dan Hollow Pipe dan variasi kondisi tumpuan jepit-bebas dan jepit-sendi; dimodelkan memiliki panjang 5 meter dan mutu baja BJ41. Berdasarkan hasil analisis tekuk elastis, nilai kekuatan desain terbesar yaitu 1.317,587 kN untuk penampang profil baja Hollow Square dengan kondisi tumpuan jepit-sendi. Persentase terbesar perbandingan perhitungan AISC terhadap pemodelan software ANSYS untuk nilai beban tekuk yaitu 5,780\% (tekuk lentur) dan $24,179 \%$ (tekuk torsi lentur) pada profil $L$ serta 38,354\% (tekuk torsi) pada profil IWF; sedangkan untuk nilai faktor panjang tekuk yaitu 2,926\% pada profil $L$.
\end{abstract}

Kata kunci: deformasi tekuk, kekuatan desain, beban tekuk, faktor panjang tekuk

\begin{abstract}
Generally, buckling deformation occurs in building columns and loaded by a large compressive axial force. This study aims to analyze the design strength of column and compare the buckling load and the buckling length factor, using both AISC and ANSYS software modeling. Columns with cross-sectional variations of IWF, C, T, L, Hollow Square and Hollow Pipe steel profiles and support variations of free-fixed and pinned-fixed; have 5-meters-length and BJ41 steel quality. Based on the elastic buckling analysis, the largest design strength is 1,317.587 kN for a Hollow Square steel profile section with a pinned-fixed support. The largest percentage of comparison between AISC calculations and ANSYS software modeling for buckling load is $5.780 \%$ (flexural buckling) and $24.179 \%$ (flexural torsional buckling) on the $L$ profile and $38.354 \%$ (torsional buckling) on the IWF profile, while the buckling length factor is $2.926 \%$ in the $L$ profile.
\end{abstract}

Keywords: buckling deformation, design strength, buckling load, buckling length factor 
Biqi Banusha, Erma Desimaliana

\section{PENDAHULUAN}

Bangunan biasanya terbuat baik dari material baja maupun beton, terdiri dari elemen-elemen struktural, seperti: pelat, balok, serta kolom. Setiap elemen ini mampu memikul gaya yang berbeda-beda, seperti: momen/lentur, lintang/geser dan normal dengan persentase yang berbeda pula. Pada umumnya, elemen struktur yang memikul gaya normal yaitu kolom. Gaya normal ini dapat berupa gaya normal tarik dan juga gaya normal tekan, sehingga terjadi tegangan. Kolom yang mengalami gaya aksial tekan akan mengalami deformasi berupa perpendekan, namun jika beban diperbesar maka akan terjadi bengkokan (deformasi tekuk) pada kolom tersebut. Untuk menghindari bahaya deformasi tekuk pada batang maka perlu diketahui nilai dari kekuatan desain $\left(\phi P_{n}\right)$ kolom.

Kapasitas aksial penampang kolom baja (profil wide flange dan pipa dengan panjang 8,5 m dan perletakan ujung bawah sendi-sendi) berdasarkan SNI 1729:2015 memiliki nilai yang lebih kecil dibandingkan hasil analisis DAM menggunakan software SAP2000 sesuai dengan hasil analisis tekuk elastis [5]. Semakin besar kelangsingan kolom baja, maka kapasitas aksial penampang kolom baja akan semakin mengecil. Perhitungan kapasitas nominal kolom berdasarkan SNI dipengaruhi oleh nilai tegangan kritis akibat koefisien tekuknya, sedangkan berdasarkan AISC dipengaruhi oleh nilai tegangan Euler akibat batas kondisi tekuk elastis atau inelastis [4].

Beban kritis maksimum kolom dari variasi penampang baja tunggal, tersusun, dan komposit yaitu terdapat pada penampang komposit dengan perletakan jepit-jepit [1]. Penampang komposit juga yang paling ekonomis apabila dibandingkan dengan kedua penampang lainnya, karena mampu memikul beban yang lebih besar dengan luas penampang yang lebih kecil. Nilai tegangan kritis maksimum kolom dari variasi penampang profil I tersusun dan $\mathrm{X}$ yaitu terdapat pada profil I tersusun dengan kondisi perletakan jepit-jepit [6].

Maka, akan dilakukan penelitian yang bertujuan untuk menganalisis perbandingan kekuatan desain kolom, nilai beban tekuk dan nilai faktor panjang tekuk terhadap variasi penampang kolom dan kondisi tumpuan, baik berdasarkan perhitungan AISC maupun pemodelan software ANSYS.

\section{TINJAUAN PUSTAKA}

\subsection{Deformasi Tekuk}

Secara umum, tekuk (buckling) biasanya terjadi pada elemen struktur yang panjang, langsing dan dibebani oleh aksial tekan. Tekuk (buckling) ini sendiri adalah perubahan bentuk (deformasi) dari suatu komponen struktur di bawah beban, seperti penekukan kolom di bawah tekanan. Kegagalan tekuk seringkali terjadi pada kolom panjang, bukan pada kolom pendek. Jika kolom pendek diberi beban berlebihan maka akan mengalami kegagalan akibat hancurnya material, sedangkan kolom panjang kegagalannya ditentukan oleh pengaruh deformasi tekuk. Kolom panjang memiliki kekakuan yang lebih besar terhadap sumbu kuat dibandingkan dengan sumbu lemahnya, sehingga akan tertekuk terhadap sumbu lemah.

\subsection{Material Baja}

Sebagai material konstruksi, baja memiliki beberapa kelebihan diantaranya kekuatan yang tinggi, kuat menahan beban tarik, sifat yang seragam, cepat dalam pemasangan, memiliki daktilitas yang tinggi, mudah disambung baik menggunakan baut maupun las dan memungkinkan untuk penggunaan kembali setelah pembongkaran. Namun di sisi lain baja juga memiliki kekurangan seperti biaya pemeliharaan yang cukup tinggi, lemah terhadap beban tekan, rentan terhadap tekuk (buckling), berisiko mengalami keruntuhan getas,

$$
\text { RekaRacana - } 182
$$


kemungkinan terjadinya karat, tidak tahan api dan menurunnya kekuatan jika diberi beban siklis. Berdasarkan [3], tegangan leleh $\left(F_{y}\right)$ dan tegangan tarik $\left(F_{u}\right)$ harus memenuhi syaratsyarat mutu yang ada pada Tabel $\mathbf{1}$.

Tabel 1. Sifat Mekanis Baja Struktural

\begin{tabular}{cccc}
\hline $\begin{array}{c}\text { Jenis } \\
\text { Baja }\end{array}$ & $\begin{array}{c}\text { Tegangan Tarik } \\
\text { Minimum, } \boldsymbol{F}_{\boldsymbol{u}}[\mathrm{MPa}]\end{array}$ & $\begin{array}{c}\text { Tegangan Leleh } \\
\text { Minimum, } \boldsymbol{F}_{\boldsymbol{y}}[\mathrm{MPa}]\end{array}$ & $\begin{array}{c}\text { Regangan } \\
\text { Minimum [\%] }\end{array}$ \\
\hline B] 34 & 340 & 210 & 22 \\
\hline B] 37 & 370 & 240 & 20 \\
\hline B] 41 & 410 & 250 & 18 \\
\hline B] 50 & 500 & 290 & 16 \\
\hline B] 55 & 550 & 410 & 13 \\
\hline
\end{tabular}

(Sumber: SNI 03-1729-2002)

Berdasarkan [3] pasal 5.1.3, sifat mekanis material baja lainnya antara lain:

Modulus elastisitas $\quad: E=200.000 \mathrm{MPa}$

Modulus geser $\quad: G=80.000 \mathrm{MPa}$

Angka poisson $\quad: \mu=0,3$

Koefisien muai $\quad: \alpha=12 \times 10^{-6} /{ }^{\circ} \mathrm{C}$

\subsection{Panjang Efektif}

Panjang efektif kolom merupakan panjang elemen struktur kolom dikalikan dengan faktor panjang tekuk $(k)$. Nilai $k$ diasumsikan tidak terjadi goyangan atau translasi pada kolom. Berdasarkan [3] pasal 7.6.3.1, nilai faktor panjang tekuk untuk beberapa kondisi tumpuan ditunjukkan pada Gambar 1.

\begin{tabular}{|c|c|c|c|c|c|c|}
\hline $\begin{array}{l}\text { Garis terputus menunjukkan } \\
\text { diagram kolom tertekuk }\end{array}$ & (o) & (b) & $\left.\right|_{1} ^{(c)}$ & (d) & $\begin{array}{c}(0) \\
1 \\
0 \\
\vdots \\
\vdots \\
\vdots \\
\vdots \\
\vdots \\
\vdots\end{array}$ & |f \\
\hline Nilai $k_{c}$ teoritis & 0.5 & 0.7 & 1.0 & 1.0 & 2.0 & 2.0 \\
\hline $\begin{array}{l}\text { Nilai } k_{c} \text { yang dianjurkan untuk } \\
\text { kolom yang mendekati kondisi } \\
\text { idiil }\end{array}$ & 0.65 & 0.80 & 1.2 & 1.0 & 2.10 & 2.0 \\
\hline Kode ujung & \multicolumn{6}{|c|}{$\begin{array}{l}\text { Jepit } \\
\text { Sendi } \\
\text { Roll tanpa putaran sudut } \\
\text { Ujung bebas }\end{array}$} \\
\hline
\end{tabular}

Gambar 1. Faktor panjang tekuk untuk beberapa kondisi tumpuan

(Sumber: SNI 03-1729-2002)

\subsection{Klasifikasi Penampang}

Klasifikasi penampang dibuat agar struktur bekerja secara optimal dan untuk menghindari terjadinya risiko tekuk lokal. Berdasarkan [2], elemen struktur yang dibebani oleh tekan aksial biasanya diklasifikasikan sebagai penampang tidak langsing dan penampang langsing. Untuk penampang tidak langsing, rasio lebar terhadap tebal elemen tekan lebih kecil dibandingkan 
$\lambda_{r}$. Jika rasio lebar terhadap tebal elemen tekan lebih besar dibandingkan $\lambda_{r}$, maka diklasifikasikan sebagai penampang langsing.

\subsection{Tekuk Elastis dan Inelastis}

Nilai tegangan kritis $\left(F_{c r}\right)$ tekuk elastis dan tekuk inelastis yang terdapat pada AISC 360-10 ditentukan dengan sebuah kondisi, yaitu sebagai berikut.

Tekuk elastis:

$$
\begin{gathered}
\frac{k L}{r_{\min }}>4,71 \sqrt{\frac{E}{F_{y}}} \\
F_{c r}=0,877 \cdot F_{e}
\end{gathered}
$$

Tekuk inelastis:

$$
\begin{gathered}
\frac{k L}{r_{\min }} \leq 4,71 \sqrt{\frac{E}{F_{y}}} \\
F_{c r}=\left(0,658^{F_{y} / F_{e}}\right) \cdot F_{y}
\end{gathered}
$$

keterangan:

$r_{\min }=$ radius girasi minimum $[\mathrm{mm}]$,

$L \quad=$ panjang kolom [mm],

$F_{e} \quad=$ tegangan Euler [MPa].

\subsection{Tegangan Tekuk}

Jika elemen struktur kolom dibebani oleh aksial tekan, maka keseluruhan elemennya akan mengalami tekuk (bukan tekuk lokal) dan memungkinkan terjadinya 3 (tiga) macam potensi tekuk, yaitu:

1. Tekuk lentur, merupakan tekuk yang terjadi akibat tertekuknya batang terhadap sumbu utama atau sumbu yang memiliki radius girasi terkecil.

2. Tekuk torsi, merupakan tekuk yang terjadi akibat terpuntirnya batang terhadap sumbu longitudinal (sumbu sejajar beban).

3. Tekuk torsi lentur, merupakan tekuk yang terjadi pada batang yang terlentur dan terpuntir secara bersamaan.

\subsection{Software ANSYS}

ANSYS adalah perangkat lunak elemen hingga yang mampu menganalisis berbagai permasalahan (Tim Langlais, 1999) dan menyelesaikan persamaan diferensial dengan membaginya menjadi bagian-bagian yang lebih kecil. Pada mulanya, software ini dinamakan STASYS (Structural Analysis System), lalu berubah menjadi ANSYS, pertama kali ditemukan oleh Dr. John Swanson tahun 1970. Fokus utama software ANSYS yaitu sebagai perangkat lunak pemodelan elemen hingga yang bertujuan untuk memecahkan sejumlah permasalahan mekanik yang berbeda, meliputi: analisis struktur statis dan dinamis, baik linear maupun nonlinear, distribusi fluida dan panas, serta elektromagnetik dan ilmu bunyi. Teknologi mekanik ANSYS menyatukan struktur dan material nonlinear. Salah satu fasilitas ANSYS yang digunakan dalam penelitian ini yaitu eigenvalue buckling analysis. Analisis eigenvalue buckling merupakan analisis elemen hingga yang bertujuan untuk menghitung besarnya beban tekuk (beban kritis yang mempengaruhi ketidakseimbangan struktur) dan ragam bentuk tekuk (deformasi tekuk yang terjadi) pada struktur elastis linear yang ideal.

$$
\text { RekaRacana - } 184
$$




\section{METODOLOGI PENELITIAN}

\subsection{Alur Penelitian}

Metode penelitian terdiri dari 2 (dua) macam, yaitu berdasarkan peraturan AISC dan berdasarkan pemodelan pada software ANSYS. Metode berdasarkan peraturan AISC ini digunakan untuk menghitung kekuatan nominal penampang (normal capacity) dari tiap penampang profil baja sehingga dapat dihitung kekuatan desain penampangnya. Pemodelan pada software ANSYS bertujuan untuk mengeluarkan output analisis berupa nilai beban tekuk (buckling load) dari tiap penampang. Beban tekuk ini akan dibandingkan dengan nilai beban tekuk dari perhitungan manual AISC, serta untuk menghitung nilai faktor panjang tekuk $(k)$.

\subsection{Data Profil dan Data Geometri Struktur}

Mutu material baja menggunakan BJ41 yang mengacu pada [3]. Panjang kolom yang dipergunakan sepanjang 5 meter dengan kombinasi perletakan jepit-bebas dan jepit-sendi. Dimensi dari masing-masing penampang ditunjukkan dari Gambar 2 sampai Gambar 8.

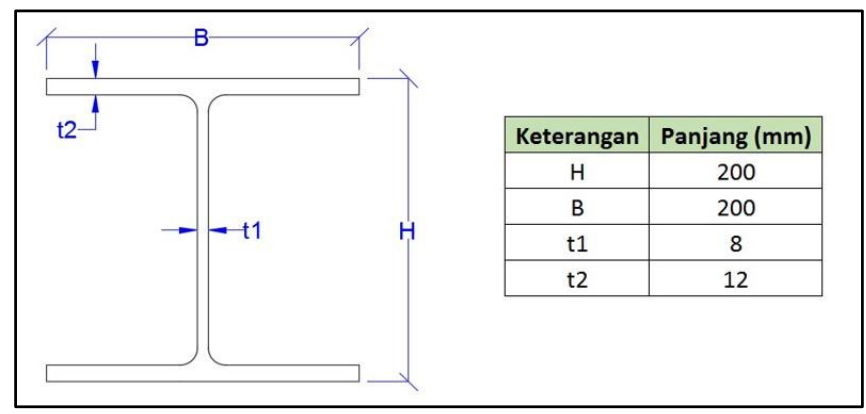

Gambar 2. Dimensi profil IWF

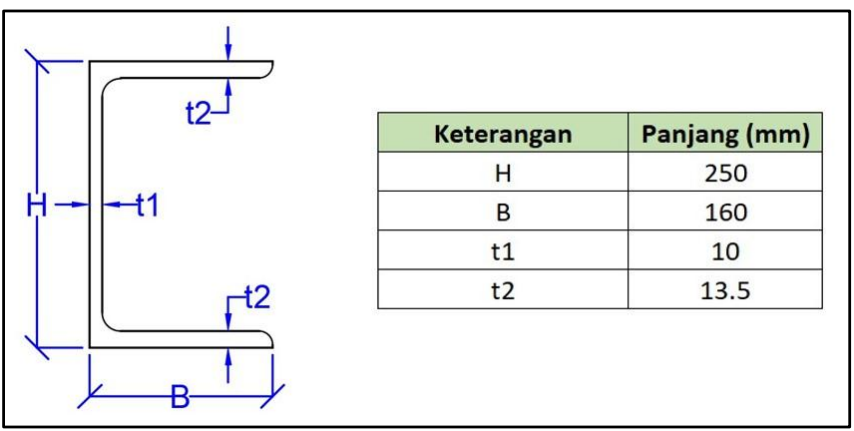

Gambar 3. Dimensi profil C/Kanal

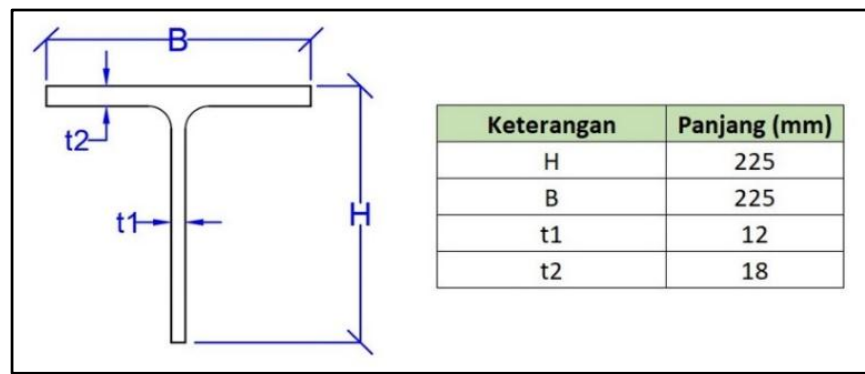

Gambar 4. Dimensi profil T 
Biqi Banusha, Erma Desimaliana

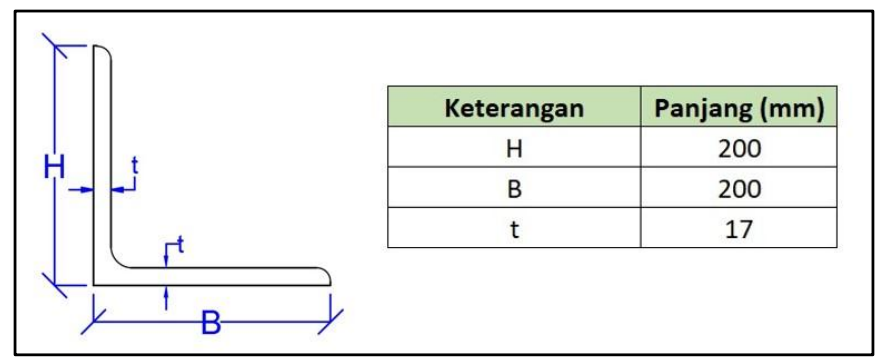

Gambar 5. Dimensi profil L Equal Angle

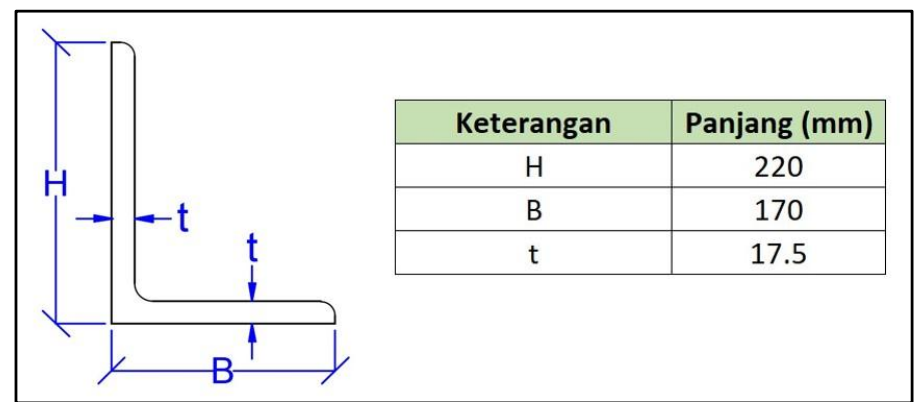

Gambar 6. Dimensi profil L Unequal Angle

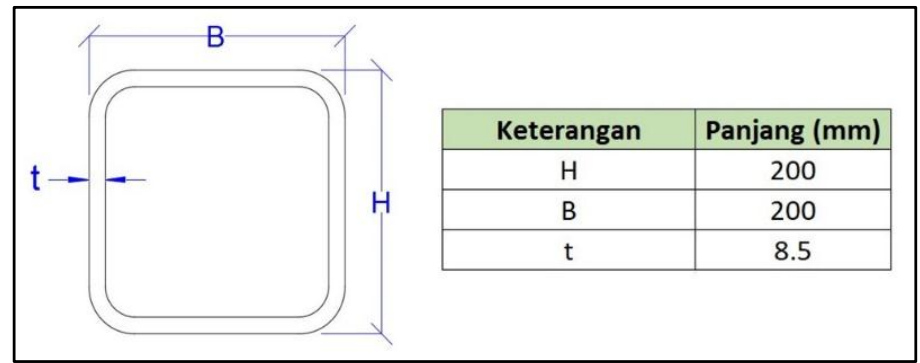

Gambar 7. Dimensi profil Hollow Square

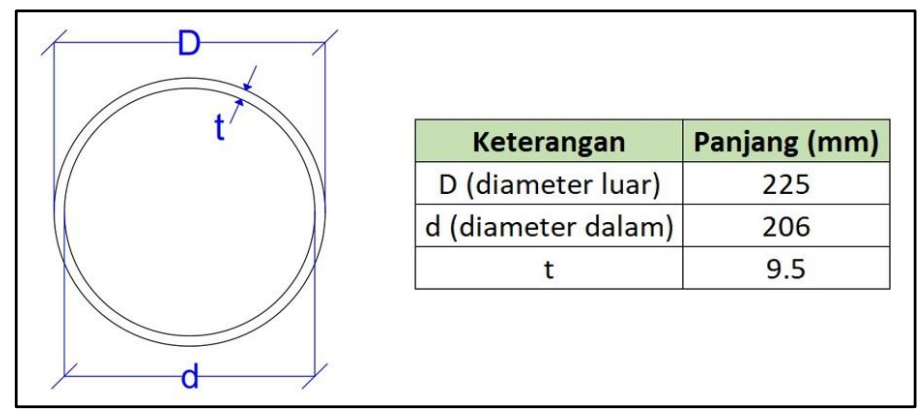

Gambar 8. Dimensi profil Hollow Pipe

\subsection{Data Luas, Momen Inersia dan Radius Girasi Penampang}

Berikut ini adalah data dari luas, momen inersia dan radius girasi dari tiap penampang yang tersaji pada Tabel 2. 
Tabel 2. Data Luas, Momen Inersia dan Radius Girasi dari Tiap Penampang

\begin{tabular}{cccccc}
\hline \multirow{2}{*}{ Penampang } & Luas $\left[\mathbf{c m}^{2}\right.$ ] & \multicolumn{2}{c}{ Momen Inersia [cm ${ }^{\mathbf{4}}$ ] } & \multicolumn{2}{c}{ Radius Girasi [cm] } \\
\cline { 2 - 6 } & $\boldsymbol{A}$ & $\boldsymbol{I}_{\boldsymbol{x}}$ & $\boldsymbol{I}_{\boldsymbol{y}}$ & $\boldsymbol{r}_{\boldsymbol{x}}$ & $\boldsymbol{r}_{\boldsymbol{y}}$ \\
\hline $\mathrm{IWF}$ & 63,530 & 4.720 & 1.600 & 8,620 & 5,020 \\
\hline $\mathrm{C} /$ Kanal & 65,500 & $6.971,375$ & $1.750,771$ & 10,317 & 5,170 \\
\hline $\mathrm{T}$ & 65,340 & $2.846,553$ & $1.711,575$ & 6,600 & 5,118 \\
\hline L Equal Angle & 65,110 & \multicolumn{2}{c}{$2.500,934$} & \multicolumn{2}{c}{6,198} \\
\hline L Unequal Angle & 65,188 & $3.175,469$ & $1.665,821$ & 6,980 & 5,055 \\
\hline Hollow Square & 65,110 & \multicolumn{3}{c}{$3.987,391$} & \multicolumn{2}{c}{7,826} \\
\hline Hollow Pipe & 64,316 & \multicolumn{3}{c}{$3.740,834$} & \multicolumn{2}{c}{7,627}
\end{tabular}

\subsection{Pemodelan Software ANSYS}

Pemodelan profil baja dilakukan pada software ANSYS, dimulai dari pembuatan dimensi profil, pemilihan bahan dan data material, menerapkan posisi dan arah beban, menerapkan posisi dan arah jenis tumpuan serta mengatur hasil output. Output dari pemodelan ini berupa nilai beban tekuk, dan selanjutnya dilakukan perhitungan manual untuk mendapatkan nilai faktor panjang tekuk.

\section{ANALISIS DAN PEMBAHASAN}

\subsection{Perhitungan Profil Baja}

Perhitungan kekuatan nominal dan kekuatan desain mengacu AISC untuk tiap penampang kolom profil baja, halmana dipengaruhi oleh perhitungan tekuk torsi untuk penampang yang memiliki sumbu simetri ganda dan perhitungan tekuk torsi lentur untuk penampang yang hanya memiliki 1 sumbu simetri saja atau tanpa sumbu simetri. Hasil perhitungan dari 7 (tujuh) penampang kolom profil baja ditunjukkan dari Tabel 3 sampai Tabel 9.

Tabel 3. Nilai $F_{e}$, Kekuatan Nominal dan Kekuatan Desain Profil IWF

\begin{tabular}{|c|c|c|c|c|}
\hline \multirow{2}{*}{$\begin{array}{l}\text { Kondisi } \\
\text { Tumpuan }\end{array}$} & \multicolumn{2}{|c|}{ Tegangan Tekuk, $F_{e}[\mathrm{MPa}]$} & \multirow{2}{*}{$\begin{array}{l}\text { Kekuatan Nominal } \\
\text { Penampang [kN] }\end{array}$} & \multirow{2}{*}{$\begin{array}{l}\text { Kekuatan Desain, } \\
\qquad \phi P_{n}[\mathbf{k N}]\end{array}$} \\
\hline & Tekuk Lentur & Tekuk Torsi & & \\
\hline Jepit-Bebas & 49,7436 & 361,6972 & 277,1505 & 249,4354 \\
\hline Jepit-Sendi & 406,0702 & 572,564 & 1227,4628 & $1.104,717$ \\
\hline
\end{tabular}

Tabel 4. Nilai $F_{e}$, Kekuatan Nominal dan Kekuatan Desain Profil C/Kanal

\begin{tabular}{|c|c|c|c|c|}
\hline \multirow{2}{*}{$\begin{array}{l}\text { Kondisi } \\
\text { Tumpuan }\end{array}$} & \multicolumn{2}{|c|}{ Tegangan Tekuk, $F_{e}[\mathrm{MPa}]$} & \multirow{2}{*}{$\begin{array}{l}\text { Kekuatan Nominal } \\
\text { Penampang [kN] }\end{array}$} & \multirow{2}{*}{$\begin{array}{l}\text { Kekuatan Desain, } \\
\qquad \phi P_{n}[\mathbf{k N}]\end{array}$} \\
\hline & Tekuk Lentur & Tekuk Torsi & & \\
\hline Jepit-Bebas & 52,761 & 107,615 & 303,075 & 272,768 \\
\hline Jepit-Sendi & 430,700 & 274,224 & $1.118,059$ & $1.006,253$ \\
\hline
\end{tabular}

Tabel 5. Nilai $\boldsymbol{F}_{c r}$ Kekuatan Nominal dan Kekuatan Desain Profil T

\begin{tabular}{|c|c|c|c|c|}
\hline \multirow{2}{*}{$\begin{array}{l}\text { Kondisi } \\
\text { Tumpuan }\end{array}$} & \multicolumn{2}{|c|}{ Nilai $F_{c r}[\mathrm{MPa}]$} & \multirow{2}{*}{$\begin{array}{l}\text { Kekuatan Nominal } \\
\text { Penampang [kN] }\end{array}$} & \multirow{2}{*}{$\begin{array}{l}\text { Kekuatan Desain, } \\
\qquad \phi P_{n}[\mathrm{kN}]\end{array}$} \\
\hline & Tekuk Lentur & Tekuk Torsi & & \\
\hline Jepit-Bebas & 75,417 & 44,549 & 291,083 & 261,975 \\
\hline Jepit-Sendi & 215,380 & 179,022 & $1.169,730$ & $1.052,757$ \\
\hline
\end{tabular}


Tabel 6. Nilai $F_{e}$ Kekuatan Nominal dan Kekuatan Desain Profil L Equal Angle

\begin{tabular}{|c|c|c|c|c|}
\hline \multirow{2}{*}{$\begin{array}{l}\text { Kondisi } \\
\text { Tumpuan }\end{array}$} & \multicolumn{2}{|c|}{ Tegangan Tekuk, $F_{e}[\mathrm{MPa}]$} & \multirow{2}{*}{$\begin{array}{l}\text { Kekuatan Nominal } \\
\text { Penampang [kN] }\end{array}$} & \multirow{2}{*}{$\begin{array}{l}\text { Kekuatan Desain } \\
\qquad \phi P_{n}[\mathrm{kN}]\end{array}$} \\
\hline & Tekuk Lentur & Tekuk Torsi & & \\
\hline Jepit-Bebas & 30,770 & 111,862 & 175,699 & 158,129 \\
\hline Jepit-Sendi & 251,179 & 471,859 & $1.073,169$ & 965,852 \\
\hline
\end{tabular}

Tabel 7. Nilai $F_{e}$ Kekuatan Nominal dan Kekuatan Desain Profil L Unequal Angle

\begin{tabular}{|c|c|c|c|c|}
\hline \multirow{2}{*}{$\begin{array}{l}\text { Kondisi } \\
\text { Tumpuan }\end{array}$} & \multicolumn{2}{|c|}{ Tegangan Tekuk, $F_{e}[\mathrm{MPa}]$} & \multirow{2}{*}{$\begin{array}{l}\text { Kekuatan Nominal } \\
\text { Penampang [kN] }\end{array}$} & \multirow{2}{*}{$\begin{array}{c}\text { Kekuatan Desain } \\
\qquad \phi P_{n}[\mathbf{k N}]\end{array}$} \\
\hline & Tekuk Lentur & Tekuk Torsi & & \\
\hline Jepit-Bebas & 26,305 & 117,975 & 150,388 & 135,349 \\
\hline Jepit-Sendi & 214,736 & 745,843 & $1.001,104$ & 900,994 \\
\hline
\end{tabular}

Tabel 8. Nilai $F_{e}$, Kekuatan Nominal dan Kekuatan Desain Profil Hollow Square

\begin{tabular}{cccc}
\hline Kondisi & Tegangan Tekuk, $\boldsymbol{F}_{\boldsymbol{e}}[\mathrm{MPa}]$ & Kekuatan Nominal \\
Tumpuan & Tekuk Lentur & 684,964 & $\begin{array}{c}\text { Kekuatan Desain, } \\
\boldsymbol{\phi} \boldsymbol{P}_{\boldsymbol{n}}[\mathbf{k N}]\end{array}$ \\
\hline Jepit-Bebas & 120,886 & $1.463,985$ & 616,467 \\
\hline Jepit-Sendi & 986,825 & $1.317,587$ \\
\hline
\end{tabular}

Tabel 9. Nilai $F_{e}$, Kekuatan Nominal dan Kekuatan Desain Profil Hollow Pipe

\begin{tabular}{cccc}
\hline Kondisi & Tegangan Tekuk, $\boldsymbol{F}_{\boldsymbol{e}}[\mathrm{MPa}]$ & $\begin{array}{c}\text { Kekuatan Nominal } \\
\text { Penampang }[\mathbf{k N}]\end{array}$ & $\begin{array}{c}\text { Kekuatan Desain, } \\
\boldsymbol{\phi} \boldsymbol{P}_{\boldsymbol{n}}[\mathbf{k N}]\end{array}$ \\
\cline { 2 - 4 } & Tekuk Lentur & 646,321 & 581,689 \\
\hline Jepit-Bebas & 114,810 & $1.438,047$ & $1.294,243$ \\
\hline Jepit-Sendi & 937,226 & & \\
\hline
\end{tabular}

\subsection{Pemodelan Profil Baja pada Program ANSYS}

Tabel 10 menampilkan perbandingan hasil perhitungan nilai beban tekuk dan nilai faktor panjang tekuk berdasarkan perhitungan AISC dan pemodelan software ANSYS. Perhitungan tekuk torsi tidak diperhitungan pada Hollow Square dan Hollow Pipe karena cenderung lebih kuat terhadap tekuk torsi meskipun memiliki 2 sumbu simetri [7].

Tabel 10. Data Nilai $k$ dan Buckling Load dari Tiap Penampang

\begin{tabular}{|c|c|c|c|c|c|c|c|c|c|}
\hline \multirow{3}{*}{ Profil } & \multirow{3}{*}{$\begin{array}{l}\text { Kondisi } \\
\text { Tumpuan }\end{array}$} & \multicolumn{6}{|c|}{ Buckling Load [kN] } & \multirow{2}{*}{\multicolumn{2}{|c|}{$\begin{array}{c}\text { Faktor Panjang } \\
\text { Tekuk [k] }\end{array}$}} \\
\hline & & \multicolumn{3}{|c|}{ Teoritis } & \multicolumn{3}{|c|}{ ANSYS } & & \\
\hline & & Lentur & Torsi & $\begin{array}{l}\text { Torsi- } \\
\text { Lentur }\end{array}$ & Lentur & Torsi & $\begin{array}{l}\text { Torsi- } \\
\text { Lentur }\end{array}$ & Teoritis & ANSYS \\
\hline \multirow{2}{*}{ IWF } & Jepit-Bebas & 315,83 & $2.297,86$ & - & 317,01 & $3.727,5$ & - & 2 & 1,99 \\
\hline & Jepit-Sendi & $2.578,18$ & $3.637,49$ & - & $2.565,10$ & $5.863,9$ & - & 0,7 & 0,7 \\
\hline \multirow{2}{*}{ C/Kanal } & Jepit-Bebas & 345,59 & - & 704,88 & 341,83 & - & 775,54 & 2 & 2,01 \\
\hline & Jepit-Sendi & $2.821,13$ & - & $1.796,17$ & $2.759,10$ & - & $1.997,8$ & 0,7 & 0,71 \\
\hline \multirow{2}{*}{$\mathrm{T}$} & Jepit-Bebas & 561,89 & - & 337,85 & 563,92 & - & 334,43 & 2 & 1,99 \\
\hline & Jepit-Sendi & $4.586,83$ & - & $2.757,97$ & $4.497,60$ & - & $2.438,3$ & 0,7 & 0,71 \\
\hline \multirow{2}{*}{$\begin{array}{l}\text { L Equal } \\
\text { Angle }\end{array}$} & Jepit-Bebas & 200,34 & - & 728,33 & 197,29 & - & 716,55 & 2 & 2,01 \\
\hline & Jepit-Sendi & $1.635,43$ & - & $3.072,27$ & $1.596,30$ & - & $3.222,3$ & 0,7 & 0,71 \\
\hline \multirow{2}{*}{$\begin{array}{l}\text { L Unequal } \\
\text { Angle }\end{array}$} & Jepit-Bebas & 171,48 & - & 769,05 & 167,95 & - & 730,17 & 2 & 2,02 \\
\hline & Jepit-Sendi & $1.399,81$ & - & $4.861,96$ & $1.318,90$ & - & $3.686,4$ & 0,7 & 0,72 \\
\hline \multirow{2}{*}{$\begin{array}{l}\text { Hollow } \\
\text { Square }\end{array}$} & Jepit-Bebas & 787,08 & - & - & 777,87 & - & - & 2 & 2,01 \\
\hline & Jepit-Sendi & $6.425,14$ & - & - & $6.206,90$ & - & - & 0,7 & 0,71 \\
\hline \multirow{2}{*}{$\begin{array}{l}\text { Hollow } \\
\text { Pipe }\end{array}$} & Jepit-Bebas & 738,41 & - & - & 741,40 & - & - & 2 & 1,99 \\
\hline & Jepit-Sendi & $6.027,85$ & - & - & $5.947,70$ & - & - & 0,7 & 0,7 \\
\hline
\end{tabular}

RekaRacana - 188 


\subsection{Persentase Perbandingan Pemodelan ANSYS dengan Persamaan Euler} Persentase ini yaitu berupa perbandingan nilai buckling load dan faktor panjang tekuk $(k)$ berdasarkan analisis pemodelan ANSYS dengan perhitungan manual. Dari perbandingan ini dapat diketahui penampang mana yang mengalami deviasi paling besar. Persentase perbandingan nilai buckling load tersaji pada Tabel 11, sedangkan untuk persentase perbandingan nilai faktor panjang tekuk $(k)$ tersaji pada Tabel 12.

Untuk kondisi tekuk lentur dan tekuk torsi lentur deviasi maksimum berada pada penampang L unequal angle, dimana masing-masing deviasinya adalah 5,780\% dan 24,179\% dengan kondisi tumpuan ujung nya adalah jepit-sendi. Sedangkan untuk kondisi tekuk torsi hanya pada penampang IWF saja dengan deviasi maksimum sebesar $38,354 \%$ pada kondisi tumpuan ujung jepit-bebas.

Untuk persentase perbandingan nilai faktor panjang tekuk $(k)$ paling besar yaitu pada profil $\mathrm{L}$ unequal angle dengan deviasi sebesar 2,926\% pada kondisi tumpuan ujung jepit-sendi.

Tabel 11. Persentase Perbandingan Nilai Buckling Load

\begin{tabular}{|c|c|c|c|c|c|c|c|c|c|c|}
\hline \multirow{3}{*}{ Profil } & \multirow{3}{*}{$\begin{array}{l}\text { Kondisi } \\
\text { Ujung }\end{array}$} & \multicolumn{6}{|c|}{ Buckling Load [kN] } & \multirow{2}{*}{\multicolumn{3}{|c|}{ Deviasi [\%] }} \\
\hline & & \multicolumn{3}{|c|}{ Teoritis } & \multicolumn{3}{|c|}{ ANSYS } & & & \\
\hline & & Lentur & Torsi & $\begin{array}{l}\text { Torsi- } \\
\text { Lentur }\end{array}$ & Lentur & Torsi & $\begin{array}{l}\text { Torsi- } \\
\text { Lentur }\end{array}$ & Lentur & Torsi & $\begin{array}{l}\text { Torsi- } \\
\text { Lentur }\end{array}$ \\
\hline \multirow{2}{*}{ IWF } & Jepit-Bebas & 315,83 & $2.297,86$ & - & 317,01 & $3.727,5$ & - & 0,37 & 38,35 & - \\
\hline & Jepit-Sendi & $2.578,18$ & $3.637,49$ & - & $2.565,1$ & $5.863,9$ & - & 0,51 & 37,97 & - \\
\hline \multirow{2}{*}{ C/Kanal } & Jepit-Bebas & 345,59 & - & 704,88 & 341,83 & - & 775,54 & 1,09 & - & 9,11 \\
\hline & Jepit-Sendi & $2.821,13$ & - & $1.796,17$ & $2.759,1$ & - & $1.997,8$ & 2,19 & - & 10,09 \\
\hline \multirow{2}{*}{$\mathrm{T}$} & Jepit-Bebas & 561,89 & - & 337,85 & 563,92 & - & 334,43 & 0,36 & - & 1,01 \\
\hline & Jepit-Sendi & $4.586,83$ & - & $2.757,97$ & $4.497,6$ & - & $2.438,3$ & 1,95 & - & 11,59 \\
\hline \multirow{2}{*}{$\begin{array}{l}\text { L Equal } \\
\text { Angle }\end{array}$} & Jepit-Bebas & 200,34 & - & 728,33 & 197,29 & - & 716,55 & 1,52 & - & 1,62 \\
\hline & Jepit-Sendi & $1.635,43$ & - & $3.072,27$ & $1.596,3$ & - & $3.222,3$ & 2,39 & - & 4,66 \\
\hline \multirow{2}{*}{$\begin{array}{c}\text { L Unequal } \\
\text { Angle }\end{array}$} & Jepit-Bebas & 171,48 & - & 769,05 & 167,95 & - & 730,17 & 2,06 & - & 5,06 \\
\hline & Jepit-Sendi & $1.399,81$ & - & $4.861,97$ & $1.318,9$ & - & $3.686,4$ & 5,78 & - & 24,18 \\
\hline \multirow{2}{*}{$\begin{array}{l}\text { Hollow } \\
\text { Square }\end{array}$} & Jepit-Bebas & 787,08 & - & - & 777,87 & - & - & 1,17 & - & - \\
\hline & Jepit-Sendi & $6.425,14$ & - & - & $6.206,9$ & - & - & 3,39 & - & - \\
\hline \multirow{2}{*}{$\begin{array}{l}\text { Hollow } \\
\text { Pipe }\end{array}$} & Jepit-Bebas & 738,41 & - & - & 741,4 & - & - & 0,4 & - & - \\
\hline & Jepit-Sendi & $6.027,85$ & - & - & $5.947,7$ & - & - & 1,33 & - & - \\
\hline \multicolumn{8}{|c|}{ DEVIASI MAX } & 5,78 & 38,35 & 24,18 \\
\hline
\end{tabular}

Tabel 12. Persentase Perbandingan Nilai Faktor Panjang Tekuk $(k)$

\begin{tabular}{|c|c|c|c|c|}
\hline \multirow{2}{*}{ Profil } & \multirow{2}{*}{ Kondisi Ujung } & \multicolumn{2}{|c|}{ Faktor Panjang Tekuk (k) } & \multirow{2}{*}{$\begin{array}{c}\text { Deviasi } \\
\text { [\%] }\end{array}$} \\
\hline & & Teoritis & ANSYS & \\
\hline \multirow[b]{2}{*}{ IWF } & Jepit-Bebas & 2 & 1,996 & 0,19 \\
\hline & Jepit-Sendi & 0,7 & 0,702 & 0,24 \\
\hline \multirow{2}{*}{ Kanal } & Jepit-Bebas & 2 & 2,011 & 0,54 \\
\hline & Jepit-Sendi & 0,7 & 0,708 & 1,12 \\
\hline \multirow{2}{*}{$\mathrm{T}$} & Jepit-Bebas & 2 & 1,996 & 0,18 \\
\hline & Jepit-Sendi & 0,7 & 0,707 & 0,96 \\
\hline \multirow{2}{*}{$\begin{array}{l}\text { L Equal } \\
\text { Angle }\end{array}$} & Jepit-Bebas & 2 & 2,015 & 0,74 \\
\hline & Jepit-Sendi & 0,7 & 0,709 & 1,20 \\
\hline \multirow{2}{*}{$\begin{array}{l}\text { L Unequal } \\
\text { Angle }\end{array}$} & Jepit-Bebas & 2 & 2,021 & 1,03 \\
\hline & Jepit-Sendi & 0,7 & 0,721 & 2,93 \\
\hline \multirow{2}{*}{$\begin{array}{l}\text { Hollow } \\
\text { Square }\end{array}$} & Jepit-Bebas & 2 & 2,012 & 0,59 \\
\hline & Jepit-Sendi & 0,7 & 0,712 & 1,71 \\
\hline \multirow{2}{*}{$\begin{array}{l}\text { Hollow } \\
\text { Pipe }\end{array}$} & Jepit-Bebas & 2 & 1,996 & 0,21 \\
\hline & Jepit-Sendi & 0,7 & 0,705 & 0,65 \\
\hline \multicolumn{4}{|c|}{ DEVIASI MAX } & 2,93 \\
\hline
\end{tabular}




\section{KESIMPULAN DAN SARAN}

\subsection{Kesimpulan}

Dari hasil analisis dan pembahasan, terdapat hal-hal yang disimpulkan sebagai berikut:

1. Analisis tekuk pada penelitian ini hanya untuk kondisi elastis saja (Euler).

2. Nilai kekuatan desain $\left(\phi P_{n}\right)$ maksimum dari 7 penampang profil baja terdapat pada profil Hollow Square dengan nilai $\left(\phi P_{n}\right)$ sebesar $1.317,587 \mathrm{kN}$.

3. Perbedaan nilai buckling load paling besar untuk kondisi tekuk lentur dan tekuk torsi lentur yaitu pada profil $L$ unequal angle, dengan nilai deviasi masing-masing sebesar $5,780 \%$ dan $24,179 \%$ pada kondisi tumpuan jepit-sendi.

4. Perbedaan nilai buckling load paling besar untuk kondisi tekuk torsi yaitu hanya pada profil IWF saja dengan nilai deviasi sebesar 38,354\% pada kondisi tumpuan jepit-bebas.

5. Perbedaan nilai faktor panjang tekuk $(k)$ paling besar yaitu pada profil $\mathrm{L}$ unequal angle dengan deviasi sebesar 2,926\% pada kondisi tumpuan jepit-sendi.

6. Nilai deviasi yang besar kemungkinan diakibatkan oleh metode analisis yang berbeda antara yang dijalankan software ANSYS dengan perhitungan manual. Metode yang dijalankan software ANSYS mengacu pada analisis elastic buckling yang mengikuti persamaan Euler, sama halnya seperti perhitungan manual yang dilakukan pada penelitian ini. Namun, analisis eigenvalue buckling pada software ANSYS seringkali menghasilkan output kelelehan yang tidak konservatif. Oleh karena itu, nilai deviasi yang telah dianalisis pun menjadi besar.

\subsection{Saran}

Pada penelitian lanjutan, perlu menganalisis tekuk pada kondisi inelastis (Engesser) dan juga kondisi tumpuan lainnya. Serta, perlu memvariasikan panjang kolom dan juga menggunakan penampang profil baja lainnya seperti king cross dan queen cross. Selain itu, pemodelan kolom dapat menggunakan software selain dari ANSYS Workbench seperti ADINA atau Abaqus dengan tujuan untuk mengetahui apakah output yang didapat relatif sama atau tidak.

\section{DAFTAR PUSTAKA}

[1] Apriyanto, W. (2007). Analisa Perbandingan Tekuk Kolom Dengan Menggunakan Profil Baja Tersusun dan Komposit. Tugas Akhir. Medan: Program Studi Teknik Sipil - Universitas Sumatera Utara

[2] Badan Standardisasi Nasional. (2020). SNI 1729:2020 Spesifikasi Untuk Bangunan Gedung Baja Struktural (ANSI/AISC 360-16, IDT). Jakarta: Badan Standardisasi Nasional.

[3] Departemen Pekerjaan Umum. (2002). SNI 03-1729-2002 Tata Cara Perencanaan Struktur Baja Untuk Bangunan Gedung. Jakarta: Departemen Pekerjaan Umum.

[4] Karomi, T. (2012). Pengembangan Grafik Desain Kuat Tekan (Pn) Kolom Baja Produk Lokal Sebagai Fungsi Dari Panjang Efektif (Le) Dengan Asumsi Kolom Berada Pada Braced Frame. Tugas Akhir. Depok: Program Studi Teknik Sipil - Universitas Indonesia

[5] Simatupang, P. H., Laiskodat, P. A. A., \& Pah, J. J. S. (2019). Hubungan Antara Kelangsingan Kolom Baja dan Kapasitas Aksial Penampang-nya Menggunakan DAM pada SAP2000 dan SNI 1729:2015. Jurnal Teknik Sipil, VII(1), 15-28.

[6] Tobing, E. N. L. (2016). Analisa Perbandingan Tekuk Kolom Aksial Profil I Tersusun dan Profil X dengan Menggunakan AISC 2010. Tugas Akhir. Medan: Program Studi Teknik Sipil -Universitas Sumatera Utara.

[7] Wiryanto, D. (2016). Struktur Baja - Perilaku, Analisis \& Desain - AISC 2010 Edisi ke-2. Tangerang: Jurusan Teknik Sipil UPH. 